\section{References}

' Bond JH, Levitt MD. Use of pulmonary hydrogen $\left(\mathrm{H}_{2}\right)$ measurements to quantitate carbohydrate absorption. Study of partially gastrectomised patients. F Clin Invest 1972;51:1219-25.

${ }^{2}$ Metz G, Drasar BS, Gassull MA, Jenkins DJA, Blendis LM. Breath hydrogen test for small intestinal bacterial colonisation. Lancet 1976 ; 668-9.

${ }^{3}$ Rhodes JM, Middleton P, Jewell DP. The lactulose $\mathrm{H}_{2}$ breath test as a diagnostic test for small bowel bacterial overgrowth. Scand $\mathcal{f}$ Gastroenterol 1979;14:333-6.

4 Bond JH, Levitt MD. Investigation of small bowel transit time in man utilising pulmonary hydrogen $\left(\mathrm{H}_{2}\right)$ measurements. F Lab Clin Med 1975; 85:546-55

5 Tadesse K, Eastwood MA. Metabolism of dietary fibre components in man assessed by breath $\mathrm{H}_{2}$ and methane. Br F Nutr 1978;40:393-6.

${ }^{6}$ Levitt MD. Production and excretion of hydrogen gas in man. $N$ Engl f Med $1969 ; 281: 122-7$.

7 Boyle BJ, Long WB, Balistrer WF, Widzer SJ, Huang N. Effect of cimetidine and pancreatic enzymes on serum and faecal bile acids and fat absorption in cystic fibrosis. Gastroenterology 1980;78:950-3.

" Dolmans MWV, Hulsberg GT. Breath $\mathrm{H}_{2}$, excretion in carbohydrate malabsorption. Nijmegen, Holland: University of Nijmegen, 1978. MD thesis.

9 Metz G, Jenkins DJA, Newman A, Blendis LM. Breath hydrogen in hyposucrasia. Lancet 1976; ; :119-20.

${ }^{10}$ Bond JH, Levitt HD. Use of breath $\mathrm{H}_{2}$ in the study of carbohydrate absorption. Am F Dig Dis 1977 ;22:379-82.

"Corbett CL, Thomas S, Read NW, Hobson N, Bergman I, Holdsworth CD. Electrochemical detector for breath $\mathrm{H}_{2}$ determination: measure- ment of small bowel transit time in normal subjects and patients with the irritable bowel syndrome. Gut $1981 ; 22: 836-40$.

12 Gillon J, Tadesse K, Logan RFA, Holt S, Sircus W. Breath $\mathrm{H}_{2}$ in pneumatosis cystoides intestinalis. Gut 1979;20:1008-11.

${ }^{13}$ McCollum JPK, Muller DPR, Harries JT. Test meal for assessing intraluminal phase of absorption in childhood. Arch Dis Child 1977;52:887-9.

14 Wood R, Hermann C, Johnson K, di Sant' Agnesse P. Pneumatosis coli in cystic fibrosis. Clinical radiological and pathological features. $A m \mathcal{F} \mathrm{Dis}$ Child 1975;129:246-8.

15 Gilat T, Hur HB, Gelman-Malachi E, Terdiman R, Peled Y. Alterations of colonic flora and their effect on the hydrogen breath test. Gut 1978; 19:602-5.

${ }^{16}$ Weber AM, Roy CC, Morin CL, Lasalle R. Malabsorption of bile acids in children with cystic fibrosis. $N$ Engl $\mathcal{F}$ Med 1973;289:1001-5.

17 Park RW, Grand RJ. Gastrointestinal manifestations of cystic fibrosis. A review. Gastroenterology $1981 ; 81: 1143-61$.

${ }^{18}$ Allen JM, Penketh ARL, Lee YC, Hodson M, Batten C, Bloom SR Elevated plasma neurotensin in adults with cystic fibrosis. Clin $\mathrm{Sci}$ $1983 ; 65: 64$.

${ }^{19}$ Matseshe JW, Go VLW, Di-Magno EP. Meconium ileus equivalent complicating cystic fibrosis in postneonatal children and young adults. Report of 12 cases. Gastroenterology 1977;72:732-6.

${ }^{20}$ Reilly RW, Krisner JB. Blind loop syndrome. Gastroenterology 1959 ;37 : 491.

${ }^{21}$ Dack GM, Petran E. Bacterial activity in different levels of intestine in isolated segments of small and large bowel in monkeys and dogs. $\mathcal{F}$ Infect Dis $1934 ; 54: 204$.

(Accepted 1 fuly 1983)

\title{
Oral iron and the bioavailability of zinc
}

\author{
N J MEADOWS, S L GRAINGER, WARWICK RUSE, P W N KEELING, R P H THOMPSON
}

\section{Abstract}

The oral bioavailability of zinc was studied in nonpregnant adults before and 24 hours after two weeks of oral supplementation with iron and folic acid. Bioavailability was greatly reduced, and the shape of the plasma curves suggested that this was due to impairment of the intestinal absorption of zinc.

The findings suggest that the reduced bioavailability of zinc occurs because of interelement competition in the bowel wall. This might induce zinc depletion.

\section{Introduction}

We have reported that depletion of zinc in maternal tissues is strongly associated with depletion of zinc in fetal tissues and with idiopathic retardation of intrauterine growth. ${ }^{1}$ The mechanisms responsible for maternal depletion are unknown, but in our local population a major cause is probably poor dietary intake, particularly as available zinc is present chiefly in expensive, high protein foods. In addition, dietary metals compete for intestinal absorption, ${ }^{2}$ and therefore routine iron supple-

Gastrointestinal Laboratory, Rayne Institute, St Thomas's Hospital, London SE1 7EH

N J MEADOWS, MB, MRCP, research fellow

S L GRAINGER, MB, MRCP, honorary senior registrar

WARWICK RUSE, MB, MRACP, research fellow

$P$ W KEELING, MD, MRCP, honorary senior registra

R P H THOMPSON, DM, FRCP, consultant physician

Correspondence to: Dr R P H Thompson. ments during pregnancy may decrease the absorption of zinc from the gut. Indeed, Solomons and $\mathrm{Jacob}^{3}$ reported that oral iron given concurrently with zinc to non-pregnant adults results in impaired oral bioavailability (or area under the plasma concentration time curve) of zinc. More prolonged effect of iron, however, has not been assessed.

We have studied the oral bioavailability of zinc given before and after oral supplementation with iron and folic acid.

\section{Patients and methods}

After a 12 hour fast 10 subjects (five men) were given $50 \mathrm{mg}$ elemental zinc (220 $\mathrm{mg}$ zinc sulphate capsules) by mouth. Two baseline $5 \mathrm{ml}$ venous blood samples were taken through a heparinised butterfly cannula before dosing, and then at 30 minute intervals for six hours. The blood was transferred into plastic heparinised tubes, the plasma separated at $400 \mathrm{~g}$ for 20 minutes at $20^{\circ} \mathrm{C}$, and two $1 \mathrm{ml}$ aliquots of plasma-each diluted with $9 \mathrm{ml} 1.0 \mathrm{M} \mathrm{HCl}$-assayed for zinc concentration by atomic absorption spectrophotometry (model IL 257, Instrumentation Laboratories).

Each subject was then given oral iron and folic acid supplements as one Pregaday tablet (ferrous fumarate $(100 \mathrm{mg}$ iron) and folic acid $350 \mu \mathrm{g}$ ) daily for 14 days and zinc bioavailability reassessed 24 hours after the last dose.

In two healthy adults the reproducibility of the areas under the plasma concentration time curves in response to the oral administration of zinc sulphate $(220 \mathrm{mg})$ was studied five times at two week intervals.

The elimination rate constant was calculated by least squares regression analysis of the log plasma zinc concentrations from 30 minutes after the peak until return to the baseline. The time to peak, peak plasma concentration, area under the curve, and elimination rate constant were compared before and after supplementation by two tailed Student's $t$ test.

All patients gave written, informed consent and the study was approved by the hospital's ethical committee. 


\section{Results}

The area under the curve after oral zinc did not change with time, and the coefficient of variation was $9.5 \%$. The mean peak plasma zinc concentration, area under the curve, and elimination rate constant were significantly lower, smaller, and slower respectively after two weeks of iron and folic acid supplementation (table). The times to achieve the peak concentration and return to baseline values, however, were unchanged (figure).

Plasma concentration time curve after oral zinc sulphate $220 \mathrm{mg}$ before and after iron and folate supplementation. Values are means (SEM in parentheses)

\begin{tabular}{lcccc}
\hline & $\begin{array}{c}\text { Area } \\
\text { under curve } \\
(\mu \mathrm{mol} / \mathrm{h} / \mathrm{l})\end{array}$ & $\begin{array}{c}\text { Time to } \\
\text { peak } \\
(\mathrm{min})\end{array}$ & $\begin{array}{c}\text { Peak } \\
\text { concentration } \\
(\mu \mathrm{mol} / \mathrm{l})\end{array}$ & $\begin{array}{c}\text { Elimination } \\
\text { rate } \\
\text { constant/ } \\
\text { hour }\end{array}$ \\
\hline $\begin{array}{l}\text { Before supplementation } \\
\text { After supplementation }\end{array}$ & $\begin{array}{c}47.9(3.8) \\
22.8(4.0)\end{array}$ & $\begin{array}{ccc}129 \cdot 0(1 \cdot 2) \\
116.0(3.1)\end{array}$ & $\begin{array}{c}37.7(2.4) \\
28.9(1.7)\end{array}$ & $\begin{array}{c}0.36(0.036) \\
0.24(0.036)\end{array}$ \\
\hline Significance of difference & $\mathrm{p}<0.01$ & $\mathrm{NS}$ & $\mathrm{p}<0.05$ & $\mathrm{p}<0.01$ \\
\hline
\end{tabular}

NS $=$ Not significant

Conversion: SI to traditional units-Zinc: $1 \mu \mathrm{mol} / 1 \approx 6.5 \mu \mathrm{g} / 100 \mathrm{ml}$.

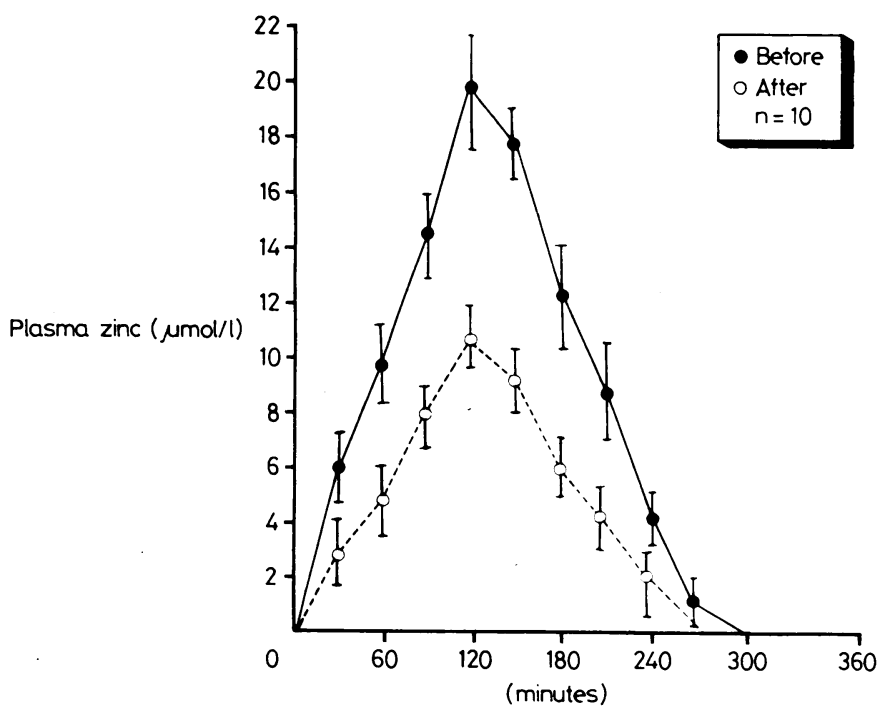

Plasma concentration time curve responses before and after iron and folic acid supplementation, corrected for baseline values. Points are means; bars are SEMs.

Conversion: SI to traditional units-Zinc: $1 \mu \mathrm{mol} / 1 \approx 6.5 \mu \mathrm{g} / 100 \mathrm{ml}$.

\section{Discussion}

Our study showed decreased oral bioavailability of zinc after iron and folic acid supplementation for two weeks in healthy non-pregnant adults. The result was not an effect of simultaneous administration of the two elements, ${ }^{3}$ for the zinc load was given 24 hours after the last iron supplement. Although we used pharmacological doses of zinc to define accurately the plasma response, a meal high in zinc content would contain at least half as much available zinc.

The most likely explanation for the decreased area under the curve and peak plasma zinc concentration and the slower elimination rate was that the intestinal absorption of zinc was impaired by the iron-folic acid tablets, and presumably by the iron rather than the folic acid, because of interelement competition. ${ }^{4}$ Alternative explanations were, however, considered. Supplementation with iron might reduce the binding of zinc to plasma proteins, increasing the concentration of free zinc and thereby leading to increased systemic clearance. This would lower peak concentrations and reduce the area under the curve, but the elimination rate constant would then be faster. If the volume of distribution of zinc increased owing to the greater availability of zinc for tissue binding lower peak plasma con- centrations would occur but the area under the curve would $\underline{T}$ not be affected. An increase in both clearance and volume of 3

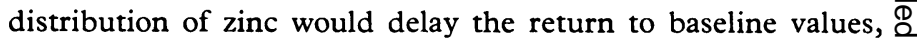
which was not observed.

Iron in the mucosa, however, by competing with zinc in $\widehat{\triangle}$ the upper small intestine, will displace a larger mass of zinc $\overline{\bar{J}}$ down the intestine and delay its absorption. Such an effect J would reduce the peak plasma concentration and area under $\infty$ the curve and, because of prolonged absorption, slow the $\frac{\pi}{2}$ apparent elimination rate, as was observed. Our results show that this effect lasts for at least 24 hours after iron ingestion.

Normally the intracellular metal binding protein metallo- $\frac{\vec{\sigma}}{0}$ thionein in the intestinal mucosa and liver probably regulates $\frac{C}{0}$ the amount of zinc being absorbed and reaching other tissues. ${ }^{5} \frac{\bar{\sigma}}{\bar{\omega}}$ Iron, however, does not bind to this protein, and so we cannot $\vec{\nabla}$ explain this competition, although zinc has been shown to impair iron absorption. ${ }^{3}$

We have previously shown that the zinc content of maternal $\overrightarrow{0}$ leucocytes in pregnancy is strongly associated with idiopathic intrauterine growth retardation, ${ }^{1}$ and suggested that, because $\vec{\omega}$ many of our mothers are from the lower social classes, depriva- $\partial$ tion of dietary zinc from expensive, high protein food was probably important in their tissue zinc depletion. Hambidge et $a l^{6}$ found that plasma zinc concentrations in pregnancy were $->$ inversely correlated with the daily dose of oral iron supplemen- के tation. This and our results in non-pregnant adults suggest that $\biguplus_{\infty}$ oral iron supplementation might induce zinc depletion. Im- $\vec{O}$ pairment of zinc absorption-particularly when the diet is poor $\vec{\omega}$ and requirements are increased, as in pregnancy-casts further 0 doubt on the wisdom of unselected iron supplementation in pregnancy, ${ }^{7}$ but we cannot yet recommend widespread supple- $\infty$

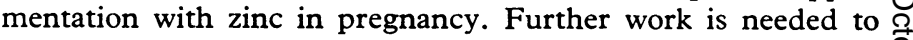
determine whether these results are applicable to smaller doses of zinc in pregnancy.

We are grateful to the Clothworkers Foundation, the Medical $\underset{\omega}{\infty}$ Research Council, Janssen Pharmaceuticals, and the Special Trustees of St Thomas's Hospital for their support. PWNK was a Medical Research Council training fellow.

\section{References}

${ }^{1}$ Meadows NJ, Ruse W, Smith MF, et al. Zinc and small babies. Lancet

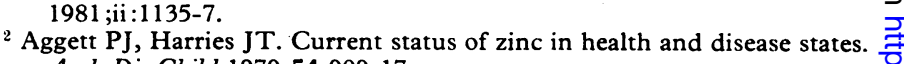
Arch Dis Child 1979;54:909-17.

${ }^{3}$ Solomons NW, Jacob RA. Studies on the bioavailability of zinc in humans: effects of heme and nonheme iron on the absorption of zinc. $A m \mathcal{F}$ Clin Nutr $1981 ; 34: 475-82$.

4 Bremner I, Mills CF. Absorption, transport and tissue storage of essential $\overline{0}$ trace elements. Philos Trans $R$ Soc Lond (Biol) $1981 ; 294: 75-89$.

${ }^{5}$ Cherian MG, Goyer RA. Metallothioneins and their role in the metabolism and toxicity of metals. Life $S_{c i}$ 1978;23:1-10.

${ }^{6}$ Hambidge KM, Krebs NF, Jacobs MA, Favie A, Guyette L, Ikle DN. Zinc nutritional status during pregnancy: a longitudinal study. $A m \mathfrak{f}$ 윽 Clin Nutr 1983;37:429-42.

${ }^{7}$ Lind T. Nutrient requirements during pregnancy. Am 7 Clin Nutr 1981; N 34:669-78.

(Accepted 28 fune 1983)

ONE HUNDRED YEARS AGO The following story, told in 0 connection with a terrible outbreak of cholera on board an emigrant steamer, illustrates a remarkable degree of confidence in the profession. The deaths on board were so numerous that, for the purpose of 0 indicating to the boatswain employed in removing the dead for burial, a cross was chalked against the berths where the corpses lay. By mistake, the fatal mark was attached to a berth where the inmate was engaged in a sound sleep. On the boatswain seizing him by the legs $\mathbb{Q}$ for removal, the intended victim called out loudly that he was not dead, but asleep-a remonstrance which drew from the old Scotch $\delta$ sailor the rejoinder, "Tut, tut, mon; the doctor knows better than you"; and who forthwith proceeded to endeavour to execute his commission. (British Medical fournal 1883;i:1079-80.) 